\title{
Education, meritocracy and opinions toward affirmative action targeted at women in Albania
}

\begin{abstract}
This article examines the role of education in the possession of opinions towards affirmative action that help women in Albania. A survey study $(n=173)$ showed that participants respond more favourably to weak preferential treatment than to strong preferential treatment. They further reveal that highly-educated people were less favourable towards affirmative action plans than lesser-educated people and were openly unfavourable towards strong preferential action. Meritocratic beliefs mediated the effects of education as regards support for strong preferential treatment, but not for weak preferential treatment. The article goes on to discuss the theoretical implications of these findings.
\end{abstract}

Keywords: affirmative action programmes, level of education, meritocratic beliefs

Situation of women in Albania

The political and socio-economic situation of Albanian women has been largely shaped by the demise of the communist system and the establishment of democracy. Even though equality between women and men was one of the proclaimed goals of the communist government, the strategies implemented to achieve this goal did not encourage the promotion and development of female characteristics. Several researchers indicate that, in order to achieve gender equality, women were forced to renounce their feminine identity to follow a masculine model (Gal and Kligman, 2000). Thus, portrayals of 'strong' women became common.

Baban (2003) indicated that women had high rates of productive employment during the communist period. However, despite the egalitarian rhetoric, the paternalist nature of communist rule reinforced patriarchal attitudes and practices. Women worked in difficult conditions, while the prevalent abuse was in the agriculture sector, where women were often spending twelve hours per day working in harsh conditions. At the same time, they were expected to assume responsibility for all the household chores.

After the fall of the communist system, the decline in egalitarian ideologies in Albania brought back the Kanun Code, primarily in the north of the country. The Kanun is an ancient Code of customary laws proclaiming, among other points, that a woman is a man's object and that, as such, she cannot be as equally respected as the man (Gjeçov, 2001).

The economic decline accompanying the fall of the communist system has had a great impact on women's participation in the labour market. In 1989, the labour participation rate of women was $77 \%$; by 1998 , it had declined to $43 \%$ and there was a further downwards movement to $39 \%$ by 2003 . 
These figures go hand-in-hand with a decline in the role of women in political life. In the local elections in 2007, there were only 33 women among the 1073 candidates nominated for mayoral posts and, of these, only nine were elected (Central Elections Commission, 2010). In the current parliament, women hold 23 of the 140 parliamentary seats (Albanian Parliament, 2010) and, at the national level, there is only one female Cabinet Minister (Council of Ministers, 2010).

Concern among politicians and civil society with the situation of women in Albania has recently increased. For instance, in 2000, in line with other European countries, all major Albanian political parties introduced a programme of electoral quotas in order to increase women's participation in politics. Furthermore, the most significant step in increasing women's presence in decision-making positions in the legislative, executive and judicial systems is the adoption by the Albanian Parliament in July 2008 of the 'Gender Equality in Society' law. In particular, all political parties must ensure, as a minimum, a representation of $30 \%$ of women in both national and local elections (Republic of Albania, 2009).

\section{The framing of affirmative action}

Affirmative action is a controversial issue in the realm of social policies (Crosby, Iyer, Clayton and Downing, 2003). That public opinion considers affirmative action to involve the preferential selection of members of minorities without regard to their level of qualifications may provide an explanation for the negative reactions toward affirmative action programmes (AAPs) (Kravitz and Platania, 1993; Northcraft and Martin, 1982). In fact, affirmative action comes in a variety of types which differ one from another in the degree to which merit and group membership are weighted in selection decisions (Konrad and Linnehan, 1995; Taylor, Doverspike and Alexander, 1995). Hence, affirmative action can be thought of as a continuum ranging at the one end from the individual to the collective at the other (Lorenzi-Cioldi, 2002; Lorenzi-Cioldi and Buschini, 2008). Toward the individual end, weak preferential treatment (sometimes called tie-break programmes) give preference to the member of the minority group if the majority and the minority candidates are similarly qualified. Toward the group end of the continuum, strong preferential treatment makes explicit the exclusive advantage of the applicant's membership group (for more specific programmes, see Kravitz, 1995; and Kravitz and Platania, 1993).

\section{Level of education and support of affirmative action}

Baudelot, Leclerq, Chatard, Gobille and Satchkova (2005) claimed that a high level of education may foster open-mindedness. One major implication of this 'liberalising effect' refers to a decrease in prejudice and negative attitudes toward different social groups: the higher the level of education, the less people show prejudice and authoritarianism; and the more tolerant, liberal and egalitarian they tend to be (Astin, 1977; Bobo and Licari, 1989; Hyman and Wright, 1979). Based on this education-tolerance thesis, one might conjecture that people with a high level of education will react more favourably toward affirmative action plans.

However, the influence of the level of education on support for affirmative action varies as a function of the type of programme in place. On the one hand, Kravitz and 
Klineberg (2000) have shown that the highly-educated are more positive than the lesseducated toward affirmative action applied under conditions of equal qualifications. On the other hand, research has shown that the highly-educated are less supportive toward strong preferential treatment concerning admission to university (Astin, 1977), access to professorship positions and in political careers (Faniko, Lorenzi-Cioldi, Buschini and Chatard, 2008; Faniko, Lorenzi-Cioldi, Buschini and Chatard, in press; Kluegel and Smith, 1983).

\section{Endorsement of meritocracy}

Why do highly-educated people show hostility toward AAPs, especially to those programmes which put weight in the decision-making process on beneficiaries' group membership? One might think that people with a high level of education would endorse meritocratic ideologies more than would others. Consistent with this suggestion, Bowles and Gintis (2002) claim that:

The educational system fosters and reinforces the belief that economic success depends essentially on the possession of technical and cognitive skills. (pp. 102-103)

There is, indeed, evidence showing that the more people are educated, the more they endorse the merit principle (Kunovich and Slomczynski, 2007); and that the more they endorse this principle, the more they oppose affirmative action (Augoustinos, Tuffin and Every, 2005).

It has been shown that education promotes system-justifying tendencies (e.g. Baer and Lambert, 1982; Baudelot and Establet, 1971; Bourdieu and Passeron, 1992; Bowles and Gintis, 2002; Doise, 1976; Guimond and Dambrun, 2003; Jackman and Muha, 1984; Trottier, 1983). Highly-educated people have greater motivation to maintain and justify the current social hierarchy (Baer and Lambert, 1982). One way to achieve system-justification is to emphasise the role of individual merit in the personal career (Jost and Banaji, 1994; Jost, Banaji and Nosek, 2004). Thus, education leads to meritocracy, and meritocracy to opposition to affirmative action policies - and especially to strong preferential treatment in so far as it does not rely on individual characteristics.

\section{The survey}

The main purpose of this research study was to examine the impact of the type of affirmative action policy in place on the favourability of public attitudes toward the policy. Consistent with the literature, we hypothesise that strong preferential treatment should receive less support than weak preferential treatment.

Our second hypothesis deals with the role of participant education. We predict an interaction between level of education and type of affirmative action policy: compared to the less-educated, the highly-educated should show more support for weak preferential treatment and less support for strong preferential treatment.

We mentioned above that endorsement of merit principles would be likely to account for this interaction, so our third hypothesis anticipates that the highly-educated will show strong endorsement of the merit principle, and that this endorsement will 
account for the relationship between level of education and support for strong preferential treatment. Thus, the type of AAP should moderate the strength of the mediated relationships between level of education and support for affirmative action via an endorsement of the merit principle. The mediated relationship should be more pronounced for strong preferential treatment than it is for weak preferential treatment.

\section{Method}

\section{Participants}

The participants in the survey were 173 undergraduate students at the University of Tiranë, Albania: seventy-eight women and twenty men in their first year of study (classified as having a low level of education); and 51 women and 24 men in their first year of their masters (classified as having a high level of education). The mean age of the participants was 20.78 years old $(S D=1.97)$, ranging from 18 to 28 years old.

\section{Procedure}

Endorsement of the merit principle

Participants completed a ten-item Preference for the Merit Principle (PMP) scale (Davey, Bobocel, Son Hing and Zanna, 1999). This scale measures individuals' preference for outcomes to be distributed on the basis of merit. Sample items are:

Sometimes it is appropriate to give a raise to the worker who most needs it, even if he or she is not the most hard working,

which is reverse-scored, and:

Members of a work group ought to receive different pay depending on the amount each person contributed.

These ten items are averaged for an overall score $(\alpha=.70)$.

\section{Scenario}

Participants read the following bogus description:

According to a recent census carried out in Albanian universities, men hold $90 \%$ of professorship positions. Following the publication of this census, the Ministry of Education has decided to apply a new hiring programme aimed at increasing the presence of women among professors.

Participants were then told that a specific affirmative action programme (Kravitz et al. 1997) had been introduced as a result. In the weak preferential treatment condition, they read that: 
This programme holds that, when a woman and a man are in competition for a professorship position, the woman should be selected if her skills are equivalent to those of the male candidate.

In the strong preferential treatment condition, participants read that:

This programme holds that, when a woman and a man are in competition for a professorship position, the woman should be selected because she is a woman.

\section{Support for affirmative action}

Support was assessed using five items derived from previous research (Kravitz and Platania, 1993; Lorenzi-Cioldi, 2002). Sample items are: 'I am in favour of applying this hiring policy,' 'This programme is a good programme' $(1=$ strongly disagree, $7=$ strongly agree; $\alpha=.90)$.

\section{Background variables}

Participants reported their age, gender and number of years in school. After completing the questionnaire, participants were fully debriefed and thanked for their participation.

\section{Results}

In accordance with previous research, the participants were more favourable to weak preferential treatment $(M=5.80 ; S D=1.36)$, than to strong preferential treatment $(M=2.88 ; S D=2.05)\left(F(1,165)=88.77 ; p<.001 ; \eta_{\mathrm{p}}^{2}=.35\right)$.

Not surprisingly, women $(M=4.61 ; S D=2.19)$ were overall more favourably disposed toward affirmative action than were men $(M=3.11 ; S D=2.23)(F(1,165)=9.34$; $\left.p<.005 ; \eta_{\mathrm{p}}^{2}=.05\right)$.

More interestingly, the main effect of participant education $(F(1,165)=8.22 ; p<$. $\left.01 ; \eta_{\mathrm{p}}^{2}=.05\right)$ demonstrated that highly-educated people $(M=3.40 ; S D=2.29)$ were, on the whole, less supportive of affirmative action policies than were lesser-educated ones $(M=4.86 ; S D=2.09)$.

However, consistent with expectations, this effect was qualified by the interaction between the Participant Education and Affirmative Action Programme variables $\left(F(1,165)=4.22 ; p<.05 ; \eta_{\mathrm{p}}^{2}=.03\right)$.

It is apparent from Figure 1 that the highly-educated showed less support for strong preferential treatment than the lesser-educated $(M s=2.02$ and 3.72; $S D s=1.45$ and 2.22 , respectively; $p<.02)$. Conversely, both groups granted similar levels of support to weak preferential treatment $(M s=5.60$ and $5.91 ; S D s=1.54$ and 1.26 , respectively). ${ }^{1}$

1 A second analysis using the same design, with the addition of participant age as a covariate, showed that the effect of education level and the effect of type of programme, and the interaction between these two variables on support for affirmative action, remained unchanged. 


\section{Moderated mediation}

To assess our main hypothesis - that the highly-educated preference for meritocracy would mediate the support of this group for strong preferential treatment, but not weak preferential treatment - we conducted a moderated mediation analysis using the statistical methods outlined in Muller, Judd and Yzerbyt (2005) and Preacher, Rucker and Hayes (2007). Such an analysis checks for four relationships:

a) the effect of level of education on support for affirmative action programmes

b) the effect of level of education on preference for merit principles

c) the interaction between preference for merit principles and type of programme on support for affirmative action

d) the conditional indirect effects of level of education on support for affirmative action programmes, via preference for merit principles. This will differ in strength across weak and strong preferential treatments.

We expected that the conditional indirect effects of the level of education would be significant concerning strong preferential treatment but not concerning weak preferential treatment.

Figure 1 - Means of support for affirmative action as predicted by education and type of affirmative action programme

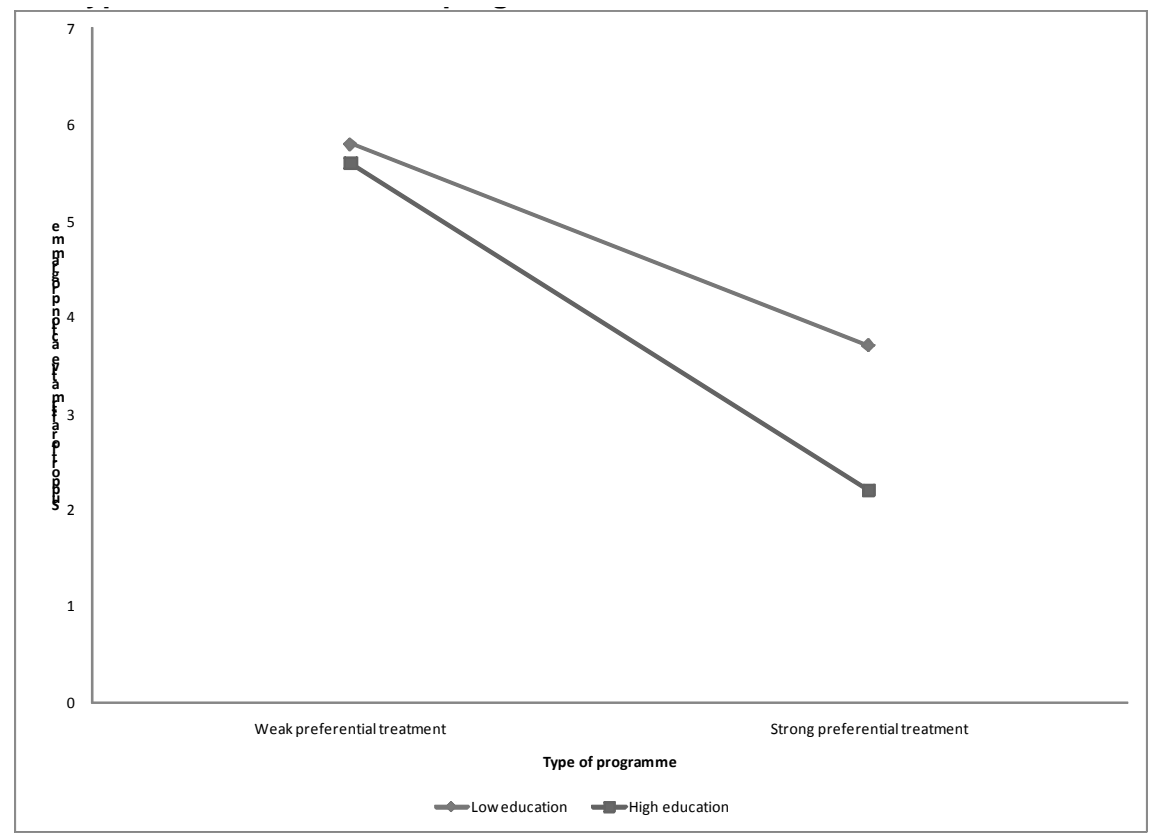

The findings supported our mediational hypothesis. There was an effect of the level of education on support for affirmative action programmes $(b=-1.01 ; p<.001)$ and on 
preference for the merit principle $(b=.52 ; p<.005)$. The interaction between preference for merit principle and type of programme $(b=-.79 ; p<.01)$ indicated that the relationship between merit and support was moderated by the strength of the AAP (see Figure 2).

In a final step to validate this finding, we examined the last condition using the procedures set out by Preacher et al. (2007). We thus assessed the magnitude of the conditional indirect effect of the independent variable (level of education) on the dependent variable (support for affirmative action) via the mediator (preference for the merit principle) for the different modalities of the moderator (weak preferential treatment vs. strong preferential treatment). The results showed that preference for the merit principle mediated the relationship between level of education and support for strong preferential treatment (coefficient $=-.35$; Boot $Z=-1.99 ; p<.05$ ), but not the relationship between level of education and support for weak preferential treatment (coefficient $=$. 06 ; Boot $\mathrm{Z}=.58 ; p=.56$ ).

Figure 2 - Mediating the role of endorsement of the merit principle on the relationship between level of education and support for weak and strong preferential treatment

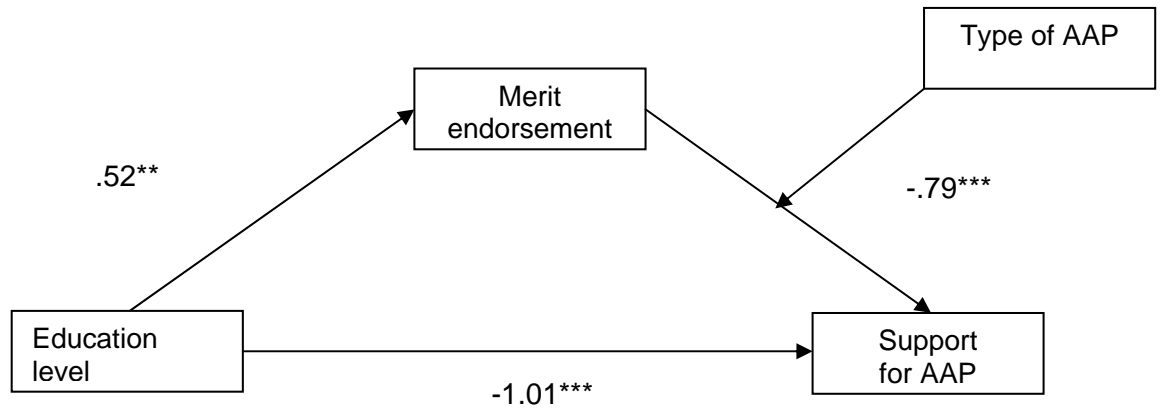

Note: $* p<.05 ; * * p<.01 ; * * * p<.001)$.

\section{Discussion}

Kravitz et al. (1997) argue that support for affirmative action may be influenced by individual factors, such as education level, the gender of the participants and the structural features of AAPs, such as type of affirmative action. These findings support their claims, but they further show a more complex picture as regards the interaction between individual and structural factors. We first discuss the role of affirmative action programme, then the influence of education and, finally, the interaction of these two factors on opinions toward affirmative action.

\section{Influence of type of programme}

In line with previous studies (Faniko et al. 2008, in press; Singer, 1996), our findings showed that participants respond more favourably to weak preferential treatment than to strong preferential treatment. Kravitz, Bludau and Klineberg (2008) explain this 
result by emphasising the non-meritocratic nature of affirmative action plans. Weak preferential treatment takes into consideration the candidate's group membership, yet it does not disregard personal merits and qualifications. Strong preferential treatment violates the principles of merit by favouring group membership to the detriment of personal characteristics. Thus, strong preferential treatment arouses opposition.

\section{Influence of education level}

The findings from previous research dealing with the role of education on support for affirmative action are inconsistent. Some research studies (Davis and West, 1984; Fine, 1992; Konrad and Hartmann, 2001; Tuch and Hughes, 1996) do not reveal any significant effects of education on support for affirmative action. Other research suggests that the influence of education on opinions toward affirmative action is strongly influenced by the type of affirmative action under consideration. Still other research reveals a negative relationship between education and support both for quota programmes (Astin, 1997) and for strong preferential treatment (Faniko et al. 2008).

Our study here revealed that support for affirmative action is more pronounced among people with a low level of education than it is among those with a high level of education. This finding runs counter to the education-tolerance thesis. Indeed, several criticisms of this thesis have been advanced. Sullivan, Pereson and Marcus (1979) argued that the relationship between education and tolerance is largely artifactual. Bourdieu and Passeron (1992) view schools as reproductive and conservative institutions rather than liberating ones. These authors comment that the school reproduces the existing social structure in that it promotes students who have cultural privilege and eliminates those whose cultural capital differs from that of the dominant group. Bourdieu and Passeron (1992) argue that:

The educational system succeeds so perfectly in fulfilling its ideological function of legitimating the established order only because this masterpiece of social mechanics succeeds in hiding, as if by the interlocking of false-bottomed boxes, the relations which, in a class society, unite the function of inculcation, i.e. the work of intellectual and moral integration, with the function of conserving the structure of the class relations characteristics of that society. (pp. 199-200)

An even stronger criticism was offered by Cohen and Lazerson (1977) who argued that students cannot learn democracy in school because the school is not a democratic place. In a similar vein, Merelman (1980) concluded that the need for order in schools leads to the creation of an environment that fosters the learning of constraint, hierarchy and inequality, rather than the values of freedom, equality and tolerance.

Our study demonstrated that highly-educated people are more opposed to strong preferential treatment, presumably because such programmes violate merit principles. However, the results did not reveal the expected difference between participants with a high and a low level of education concerning the level of support for weak preferential treatment. How can we interpret this null finding? The results showed that the highlyeducated are more likely to emphasise meritocratic ideologies compared to the lessereducated. Accordingly, they refuted the implementation of strong preferential treatment 
more than they did the implementation of weak preferential treatment. Nonetheless, they could accept weak preferential treatment to the same extent as the lesser-educated in so far as this treatment did not conflict with meritocratic ideologies.

The results of this study substantiate our moderated mediation hypothesis, i.e. that the preference for the merit principle mediates the relationship between level of education and support for strong preferential treatment, but not for weak preferential treatment. This suggests that education contributes to the belief that professional promotion should be strongly related to personal merit rather than to group membership. These beliefs provoke the rejection of strong preferential treatment, in so far as it does not take into account personal qualifications, but not the rejection of weak preferential treatment, in so far as it favours the female applicant if her qualifications are equivalent to those of the male applicant.

\section{Implementation of affirmative action programmes}

Despite the large diversity of affirmative action programmes, only two, very different, forms of affirmative action have been examined in this study. We decided to assess support for these two forms because the results derived from the study may be useful for the implementation of affirmative action programmes in several countries. Strong preferential treatment is similar to quota programmes. Both programmes are based primarily, if not solely, on demographic status. It was mentioned above that the Albanian government is currently implementing quota programmes with the target of improving women's access to political positions; while France is considering introducing a quota of $40 \%$ women in decision-making positions in French companies (Ministère du Travail, des Relations Sociales, de la Famille, de la Solidarité et de la Ville, 2009). Swiss universities (e.g. Geneva University) have introduced weak preferential treatment for women applying for professorship positions.

Thus, our research has practical implications for decision-makers in Europe who aim to use affirmative action principles in strategies for minority empowerment.

\section{References}

Albanian Parliament (2010) Statistics [retrieved 5 September 2010 from: http:// www.parlament.al/]

Astin, A. W (1977) Four critical years San Francisco: Josey-Bass.

Augoustinos, M, K. Tuffin and D. Every (2005) 'New racism, meritocracy and individualism: Constraining affirmative action in education' Discourse and Society 16, 315-340.

Baban, A (2003) Domestic violence against women in Albania New York: UNICEF. [retrieved 5 September 2010 from: http://www.unicef.org/albania/domviol_eng.pdf].

Baer, D. E and R. D. Lambert (1982) 'Education and support for the dominant ideology' Canadian Review of Sociology and Anthropology 19: 173-195.

Baudelot, C and R. Establet (1971) L'école capitaliste en France [The capitalist school in France] Paris: Maspero. 
Baudelot, C, F. Leclercq, A. Chatard, B. Gobille and E. Satchkova (2005) Les effets de l'éducation [The effects of education] Paris: La Documentation Française.

Bobo, L, and F. C. Licari (1989) 'Education and political tolerance: Testing the effects of cognitive sophistication and target group affect' Public Opinion Quarterly 53: 285-308.

Bourdieu, P, and J-C. Passeron (1992) Reproduction in education, society and culture London: Sage.

Bowles, S, and H. Gintis (2002) 'Schooling in capitalist America revisited' Sociology of Education 75: 1-18.

Central Elections Commission (2010) Distribution of mandates for councillors as per electoral subjects [retrieved 5 September 2010 from: http://www.cec.org.al/2004/ zgjedhvendorefiles/2007/Rezultatet/rezultate\%20perfundimtare/kryetar.pdf].

Cohen, D and M. Lazerson (1997) 'Education and the corporate order' in J. Karabel and A. H. Hasley (Eds.) Power and ideology in education New York: Oxford University Press, pp. 373-386.

Council of Ministers (2010) The cabinet [retrieved 5 September 2010 from: http:// www.keshilliministrave.al $/$ fq $=$ showcabzvm\&gj=gj2

Crosby, F, A. Iyer, S. Clayton and R. Downing (2003) 'Affirmative action: Psychological data and the policy debates' American Psychologist 58: 93-115.

Davey, L. M, D. R Bobocel, L. S. Son Hing and M. P. Zanna (1999) 'Preference for the merit principle scale: An individual difference measure of distributive justice preferences' Social Justice Research 12: 223-240.

Davis, C. E, and J. P. West (1984) 'Implementing public programs: Equal employment opportunity, affirmative action, and administrative policy options' Review of Public Personnel Administration 4: 16-30.

Doise, W (1976) L'articulation psychosociologique et les relations entre groupes [Psycho-sociological articulation and relations between groups] Brussels, Belgium: De Boeck.

Faniko, K, F. Lorenzi-Cioldi, F. Buschini and A. Chatard (in press) 'The Influence of Education on Attitudes toward Affirmative Action: The Role of the Policy's Strength' Journal of Applied Social Psychology.

Faniko, K, F. Lorenzi-Cioldi, F. Buschini and A. Chatard (2008) 'Affirmative action plans that assist women's mobility in Albania: The paradox of education' in S. Fischer and H. Pleines (Eds.) Crises and conflicts in post-socialist societies. The role of ethnic, political and social identities Vol. 4: 209-220, Stuttgart, Germany: Ibidem-Publishers.

Fine, T. S (1992) 'The impact of issue framing on public opinion: Toward affirmative action programs' The Social Science Journal 29: 323-334.

Gal, S and G. Kligman (2000) Reproducing gender: Politics, publics and everyday life after socialism Princeton, NJ, US: Princeton University Press. 
Gjeçov, Sh (2001) Kanuni i Lek Dukagjinit [Kanun of Lek Dukagjini] Tiranë, Albania: Geer.

Guimond, S, and M. Dambrun (2003) 'La construction sociale et scolaire du stigmate' ['Social and school construction of stigma'] in J-C. Croizet and J-P. Leyens (Eds.) Mauvaises réputations [Bad reputations] Paris: Armand Colin, pp. 177-213.

Hyman, H. H, \& C. R. Wright (1979) Education's lasting influence on values Chicago: University of Chicago Press.

Jackman, M. R, and M. J. Muha (1984) 'Education and intergroup attitudes: Moral enlightenment, superficial democratic commitment, or ideological refinement?' American Sociological Review 49: 751-769.

Jost, J. T and M. R. Banaji (1994) 'The role of stereotyping in system justification and the production of false consciousness' British Journal of Social Psychology 33: $1-27$.

Jost, J. T, M. R. Banaji and B. A. Nosek (2004) 'A decade of system justification theory: Accumulated evidence of conscious and unconscious bolstering of the status quo' Political Psychology 25: 881-919.

Kluegel, J. R and E. R. Smith (1983) 'Affirmative action attitudes: Effects of selfinterest, racial affect, and stratification beliefs on whites' views' Social Forces 61: 797-824.

Konrad, A. M, and L. Hartman (2001) 'Gender differences in attitudes toward affirmative action programs in Australia: Effects of beliefs, interests, and attitudes toward women' Sex Roles 34: 415-432.

Konrad, A. M, and F. Linnehan (1995) 'Formalized HRM structures: Coordinating equal employment opportunity or concealing organizational practices?' Academy of Management Journal 38: 787-820.

Kravitz, D. A (1995) 'Attitudes toward affirmative action plans directed at Blacks: Effects of plan and individual differences' Journal of Applied Social Psychology 25: 2192-2220.

Kravitz, D. A, T. Bludau and S. L. Klineberg (2008) 'The impact of anticipated consequences, respondent group, and strength of affirmative action plan on affirmative action attitudes' Group and Organization Management 33: 361-391.

Kravitz, D. A, D. A. Harrison, M. E. Turner, E. L. Levine, W. Chaves and M. T. Brannick (1997) Affirmative action: A review of psychological and behavioral research Bowling Green, Ohio, US: Society for Industrial-Organizational Psychology.

Kravitz, D. A and S. L. Klineberg (2000) 'Reactions to two versions of affirmative action among Whites, Blacks, and Hispanics' Journal of Applied Psychology 85: 597-611. 
Kravitz, D. A and J. Platania (1993) 'Attitudes and beliefs about affirmative action: Effects of target and of respondent sex and ethnicity' Journal of Applied Psychology 78: 928-938.

Kunovich, S and K. M. Slomczynski (2007) 'Systems of distribution and a sense of equity: A multilevel analysis of meritocratic attitudes in post-industrial societies' European Sociological Review 23: 649-663.

Lorenzi-Cioldi, F (2002) Les représentations des groupes dominants et dominés. Collections et agrégats [Social representations of dominant and dominated groups. Collections and aggregates] Grenoble, France: Presses Universitaires de Grenoble.

Lorenzi-Cioldi, F and F. Buschini (2008) 'When the glass ceiling collapses, walls are erected: Positive and negative consequences of psychological essentialism in affirmative action' in S. Badaloni, C. A. Drace, O. Gia, C. Levorato and F. Vidotto (Eds.) Under-representation of women in science and technology Padova, Italy: Cleup, pp. 27-40.

Merelman, R. M (1980) 'Democratic politics and the culture of American education' American Political Science Review 74: 319-332.

Ministère du Travail, des Relations Sociales, de la Famille, de la Solidarité et de la Ville (2009) Rapport préparatoire à la concertation avec les partenaires sociaux sur l'égalité professionnelle entre les femmes et les hommes [Report for the consultation of the social partners on the professional equality of women and men] [retrieved 24 August 2009 from: http://www.travail-emploi-sante.gouv.fr/IMG/ pdf/Rapport egalite8-07-09.pdf.

Muller, D, V. Yzerbyt and C. M. Judd (2005) 'When moderation is mediated and mediation is moderated' Journal of Personality and Social Psychology 89: 852-863.

Northcraft, G. B and J. Martin (1982) 'Double jeopardy: Resistance to affirmative action from potential beneficiaries' in B. Gutek (Ed.) Sex role stereotyping and affirmative action policy Institute of Industrial Relations, University of California: Los Angeles, pp. 81-130.

Preacher, K. J, D. D. Rucker and A. F. Hayes (2007) 'Assessing moderated mediation hypotheses: Theory, methods, and prescriptions' Multivariate Behavioral Research 42: 185-227.

Republic of Albania (2009) Kodi Zgjedhor i Republikës së Shqipërisë (Miratuar me ligjin nr.10019, datë 29.12.2008) [The Electoral Code of the Republic of Albania (Approved by Law No. 10 019, dated 29.12.2008)] Tiranë: Republic of Albania.

Singer, M. S (1996) “"Merit", "preferential” or "diversity-based” selection: Effect of information frame and informant gender on the public's views on preferential treatment in selection' International Journal of Selection and Assessment 4: 1-11.

Sullivan, J, J. Piereson and G. Marcus (1979) 'An alternative conceptualization of political tolerance: Illusory increases 1950s-1970s’ American Political Science Review 78: 781-794. 
Taylor, M. A, D. Doverspike and R. A. Alexander (1995) 'Message effects on the perceptions of fairness of gender-based affirmative action: A cognitive response theory based analysis' Social Justice Research 8: 285-303.

Trottier, C. R (1983) 'Le processus de socialisation à l'école' ['Socialization process at school'] in R. Cloutier, J. Moisset and R. Ouellet (Eds.) Analyse sociale de l'éducation [Social analysis of education] Montréal, Canada: Boréal, pp. 87-104.

Tuch, S. A and M. Hughes (1996) 'Whites' racial policy attitudes' Social Sciences Quarterly 77: 723-741. 